\title{
CAPITANIA-MOR DE SERGIPE DEL REI E GOVERNO DA ILHA DE SANTA CATARINA: ESTATUTOS. JURISDICÕES E HIERARQUIAS
}

AUGUSTO DA SILVA *

UNIVERSIDADE FEDERAL DE SERGIPE

ARACAJU - SERGIPE - BRASIL

O artigo propõe uma análise comparativa da história institucional da capitania-mor de Sergipe del Rei (1590-1820) e do governo da ilha de Santa Catarina (1738-1821). Observando as semelhanças e diferenças acerca do estatuto jurídico-político, dos vínculos de subordinação aos governos superiores, da remuneração dos seus chefes militares, assim

RESUMO

ABSTRACT como também dos principais órgãos civis e militares que neles se montaram, busca-se identificar as características fundamentais e a posição hierárquica desses dois estabelecimentos na estrutura da administração portuguesa na América.

Palavras-chave: Capitania-mor; Sergipe del Rei; Governo subalterno; Ilha de Santa Catarina.

The article aims to present a comparative analysis of the institutional history of Sergipe del Rei captaincy major (1590-1820) and Santa Catarina Island government (1738-1821). Observing similarities and differences regarding the legal-political status, subordination ties to higher governments, of their military leaders remuneration, as well as the main civil and military bodies that set up in them, we seek to identify the fundamental characteristics and the hierarchical position of these two establishments in the Portuguese administration structure in America.

Keywords: Captaincy major; Sergipe del Rei; Subordinate government; Santa Catarina Island. 


\section{INTRODUCÃO}

O termo capitania teve uso flexível, significando coisas distintas nos diferentes espaços do império português na Época Moderna. De início, consistia na divisão administrativa das conquistas portuguesas no ultramar, incluindo tanto as capitanias-governadorias (praças e fortalezas-feitorias da costa africana e do oriente) de feição militar e temporária, quanto as capitanias-donatarias das terras de colonização (Madeira, Açores, Cabo Verde, São Tomé, Brasil e Angola) de caráter hereditário. ${ }^{1}$ Ocorre que a amplidão dos espaços a dominar e a variedade de situações que cada caso colocava no decorrer do processo de conquista exigiu soluções políticas diversas. ${ }^{2}$

Em tese, as capitanias deveriam ter sempre à frente a figura do capitão: aquele "que manda um exército inteiro, ou uma armada grande, como Capitão-General", ou "o que manda um corpo mais pequeno, como Capitão-Mor". 3 Ao título de capitão foi comum também agregar o de governador, em função da distinção honorífica do detentor do cargo e/ou do próprio estabelecimento que ele ia comandar. A disposição permanente para a guerra e a posterior institucionalização jurídica e fazendária tinha por função proteger os territórios dos reinos europeus concorrentes, dos povos originais insubmissos e, em certos casos, dos escravos refugiados nos mocambos. Com base na extorsão de mercadorias e tributos, toda essa estrutura deveria ser mantida - se preciso, coercitivamente - pelos próprios súditos do rei, a quem ele dizia proteger. ${ }^{4}$

Na América Portuguesa, a reversão das capitanias hereditárias à coroa - processo que se inicia já no século XVI e se conclui no período pombalino ${ }^{5}$ - resultou na criação de outras instituições, como as capitanias-gerais, sob o comando de um governador e capitão-general; as capitanias-mores, tendo à frente um capitão-mor das tropas regulares (com soldo); e os governos subalternos ao Rio de Janeiro, cujo mando ficava a cargo de um governador, na maioria dos casos com a patente de coronel ("governo" aqui, para além da "ação de governar"

\footnotetext{
${ }^{1}$ ENCICLOPÉDIA Luso-Brasileira de Cultura. Lisboa: Verbo, s/d, vol. IX, p. 915 (verbete "Capitania").

${ }^{2}$ HESPANHA, A. M.; SANTOS, M. C. “Os poderes num império oceânico”. In: HESPANHA, A. M. (Coord). História de Portugal - v. 4, O Antigo Regime (1620-1807). Lisboa: Estampa, 1998, pp. 355-356.

${ }^{3}$ BLUTEAU, R. Vocabulário Portuguez e Latino... Coimbra: Collegio das Artes da Companhia de Jesu, 1712, 8v (v. II. - verbete “capitão").

${ }^{4}$ TILLY, C. "War Making and State Making as Organized Crime". In: EVANS, P. B.; RUESCHEMEYER, D.; SKOCPOL, T. (Eds). Bringing the State Back In. Cambridge: Cambridge Universtiy Press, 1985, p. 169-191.

${ }^{5}$ SALDANHA, A. V. de. As capitanias do Brasil: antecedentes, desenvolvimento e extinção de um fenómeno atlântico. Lisboa: Comissão Nacional para as Comemorações dos Descobrimentos Portugueses, 2001.
} 
tinha também o sentido de um território de jurisdição, "uma província, que tem governador"6). Houve casos ainda de donatarias que se transformaram em comarcas de capitanias-gerais (caso de Ilhéus e Porto Seguro com a Bahia), mas mantiveram na vila principal um capitão-mor de ordenanças (sem soldo). Todos esses novos cargos instituídos por nomeação régia temporária.

Vistas de perto, cada uma das unidades coloniais apresentava singularidades. Colônia do Sacramento, por exemplo, embora tivesse à frente a figura de um governador manteve-se sempre como uma praça militar, uma cidadela com finalidades comerciais. Outras vilas e praças militares, a exemplo de Porto Calvo, Alagoas e Rio de São Francisco, subordinadas à Pernambuco, eram chamadas de capitanias e ficavam sob o comando de um capitão-mor de ordenanças. ${ }^{7}$ Não havia, portanto, um padrão único a ser seguido. As formas institucionais adotadas variaram muito, o que torna insuficiente aquela divisão simples feita pela historiografia da história administrativa do Brasil entre capitanias-gerais e capitanias subalternas. ${ }^{8}$

Proponho a seguir, por meio da análise comparativa, avançar na compreensão do estatuto, vínculos de subordinação e estrutura da administração da capitania-mor de Sergipe del Rei (1590-1820) e do governo da ilha de Santa Catarina (1738-1821). Segundo Marc Bloch, são necessárias duas condições para uma história comparada: a existência, por um lado, de certa similaridade entre os fatos observados, e, por outro lado, certa diferença nos ambientes em que esta similaridade ocorreu. ${ }^{9}$ Condições verificáveis nos dois estabelecimentos aqui propostos para análise. Como pontos comuns podemos destacar: ambos foram administrados pelo poder régio e não por donatários; mantiveram-se institucionalmente subalternos a governos superiores (Sergipe à Bahia; Santa Catarina ao Rio de Janeiro); sofreram um e outro invasão estrangeira (os holandeses em Sergipe, entre 1637 e 1648; os espanhóis na ilha de Santa Catarina, entre

\footnotetext{
${ }^{6}$ BLUTEAU, 1712 (v. IV - verbete "governo").

${ }^{7}$ Cf. ROLIM, A. Jurisdição militar, inquisitorial e territorial no sul de Pernambuco: contribuição a uma arquitetura dos poderes nas capitanias de Porto Calvo, Alagoas e Rio de São Francisco (1655-1712). Revista Ultramares, n. 2, v. 2, jan/jul. p. 130-159, 2012; CURVELO, A. A. S. de C. Governar Pernambuco e as "capitanias anexas": o perfil de recrutamento, a comunicação política e as jurisdições dos governadores da capitania de Pernambuco (c.1654 - c.1756). (Tese de Doutorado) Programa Interuniversitário de Doutoramento em História. Universidade de Lisboa, ISCTE - Instituto Universitário de Lisboa, Universidade Católica Portuguesa e Universidade de Évora, 2019 , p. 136.

${ }^{8}$ Ver, dentre outros: PRADO Jr. C. Formação do Brasil Contemporâneo: colônia. 23 ed. São Paulo: Brasiliense, 1999, p. 305; VIANNA, H. História do Brasil colonial. São Paulo, 1945, p. 69; AVELlAR, H. de A. Administração Pombalina. 2 ed. Brasília: Fundação Centro de Formação do Servido Público; Universidade de Brasília, 1983 (vol. 5 - História Administrativa do Brasil), p. 54; WEHLING, A. Administração Portuguesa no Brasil de Pombal a D. João (1777-1808). Brasília-DF: Fundação Centro de Formação do Servido Público, 1986 (vol. 6 História Administrativa do Brasil), p. 38

${ }^{9}$ BLOCH, M. Para uma história comparada das sociedades europeias. In: Id. História e historiadores. Lisboa: Teorema, 1948, p. 121.
} 
1777 e 1778); consolidaram-se como unidades produtivas relevantes, fundadas amplamente no trabalho escravo, indígena primeiro, africano depois; tiveram estrutura político-administrativa similar; seus chefes militares possuíam semelhantes limites jurisdicionais de poder; tornaramse províncias do império independente do Brasil.

Mas se à primeira vista tudo parece ser igual, logo se vê que há em tudo algo de distinto. As dinâmicas políticas, sociais e econômicas do processo de conquista e colonização, nos diferentes espaços e tempos, deram a cada uma dessas unidades coloniais uma formação histórica singular. Daí resultando também a posição específica que elas ocuparam na estrutura da administração portuguesa na América.

\section{A CAPITANIA-MOR DE SERGIPE DEL REI: ESTATUTO E CONDICÃO DE SUBALTERNIDADE}

Sergipe del Rei, como o próprio nome indica, foi uma capitania real, ${ }^{10}$ criada após a reversão da donataria de Francisco Pereira Coutinho para a coroa. ${ }^{11}$ Soldados e padres missionários, no último quartel do século XVI, transpuseram o rio Real de modo a fechar os espaços entre a Bahia e a capitania de Pernambuco. O avanço colonizador se impôs com a expulsão, a escravização, o aldeamento e, principalmente, o extermínio dos povos originários. Ao mesmo tempo, buscavam barrar o acesso de nações estrangeiras na região, sobretudo dos franceses, que negociavam os produtos da terra com os nativos. ${ }^{12}$

$\mathrm{Na}$ foz do rio Sergipe (também chamado Cotinguiba), Cristóvão de Barros ${ }^{13}$, no comando de um exército de aproximadamente três mil homens, fundou, em 1590, um arraial fortificado com o nome de cidade de São Cristóvão (topônimo intercambiável por todo o período colonial com cidade de Sergipe), sede da nova capitania. Num movimento crescente de

\footnotetext{
${ }^{10}$ Diz FREIRE, F., em História de Sergipe (1575-1855). 3ª ed. São Cristóvão: Ed UFS, 2013, p. 85, que “del Rei” servia também para a diferenciar do engenho Sergipe do Conde, localizado no recôncavo baiano.

${ }^{11}$ Embora a instalação do governo-geral com Tomé de Souza comece em 1549, a transação da capitania com Manoel Pereira Coutinho, primogênito do Francisco, só se efetivou em 5.9.1573, segundo PRADO, I. do. A Capitania de Sergipe e suas Ouvidorias (Memória sobre questões de limites). 2 ed. São Cristóvão: Editora da UFS; Aracaju: IHGSE, 2015, p. 33, ou, em 16.8.1576, segundo VARNHAGEN, F. A. de. História Geral do Brasil. (Tomo I). 5 ed. São Paulo: Edições Melhoramentos, 1956, p. 237.

12 Sobre esse processo ver, sobretudo: FREIRE, 2013, p. 83-105; NUNES, M. T. Sergipe colonial I. 2 ed. São Cristóvão: Ed. UFS; Aracaju: Fundação Oviedo Teixeira, 2006, p. 17-40.

13 Cristóvão Cardoso de Barros foi um fidalgo português. Chegou ao Brasil em 1566, na mesma nau que trouxe Estácio de Sá, a quem ele deveria auxiliar. Estabeleceu-se no Rio de Janeiro como provedor-mor da fazenda e proprietário de um poderoso engenho de açúcar. Comandou tropas contra os franceses na Guanabara e, depois, contra ingleses e indígenas na Bahia. Dos três mil homens da sua expedição ao rio Real, em 1589, calcula-se que um terço era formada por índios tapuias e mestiços.
} 
ocupação do espaço com a doação de sesmarias, instalação de vilas e formação das fazendas e currais - processo interrompido pelo conflito com os holandeses - consolidou-se, no decorrer dos séculos XVII e XVIII, essa unidade colonial. Unidade, diga-se, não como uma instituição estatal perfeitamente territorializada. Primeiro, porque a área de circunscrição jurisdicional dos capitães-mores (a capitania) nem sempre coincidia com a dos ouvidores (a comarca) e a dos vigários (a comarca eclesiástica), embora tivessem eles um mesmo centro como sede, a cidade de São Cristóvão. Segundo, porque nas zonas limítrofes (nos termos das vilas) não se encontravam linhas de fronteira, mas, na perspectiva do colonizador, a extensão legítima de um espaço político, ainda que "vazio". ${ }^{14}$

As nomeações dos seus comandantes militares seguiram, com poucas variações, a cartapatente passada a Jorge de Barros Leite, em Lisboa, a 20 de março de 1686: "Hei por bem de fazer-lhe mercê do posto de Capitão-mor da capitania de Sergipe de El Rei por tempo de três anos (...). Pelo que mando ao meu Governador e Capitão-Geral do Estado do Brasil lhe dê posse (...)". ${ }^{15}$ Com o título de "governador" aparece o mesmo Barros Leite em seu segundo mandato (1712-1714), nomeado como "Mestre de Campo governador da capitania" e Joaquim José Martins (1796-1803), que se autoproclamava "Governador e Capitão-Mor de Sergipe". ${ }^{16}$ Tratava-se de uma distinção honorífica, não de funções. Barros Leite, pouco antes de sua segunda nomeação, havia alcançado a patente de tenente-general, mas manteve no exercício do cargo o mesmo soldo, privilégios e obrigações dos demais capitães-mores.

\footnotetext{
${ }^{14}$ Portanto, não faz sentido buscar limites muito precisos entre essas diferentes instituições na Época Moderna. As dúvidas que surgiam sobre a quem pertencia determinada jurisdição eram resolvidas, em última instância, pelo poder régio. Os limites só se tornaram de fato uma necessidade após a primeira Constituição republicana (1891), quando as rendas advindas do imposto de exportação passaram a ficar com os estados. Entre Sergipe e Bahia os litígios territoriais que daí decorreram deram origem a acirrada e profícua disputa histórico-jurídica. Em defesa do primeiro temos, dentre outros, os estudos de: LIMA Jr., F. de C. História dos limites entre Sergipe e Bahia. São Cristóvão: Ed. da UFS; Aracaju: IHGSE, 2015 [1919]; e PRADO, 1919. Em defesa do segundo, destacam-se: AMARAL, B. do. Limites do Estado da Bahia (Bahia - Sergipe). Salvador: Imprensa Oficial do Estado, 1916; e VIANA, F. V. Estudo sobre a origem histórica dos limites entre Sergipe e Bahia. Salvador: Typ. e Enc. Do Diário da Bahia, 1891.

${ }^{15}$ Biblioteca Nacional do Rio de Janeiro, Documentos Históricos (DHBN), 1935, v. 29, p. 79. Ver também as cartas-patentes de Paulo Barbosa, de 6.4.1630, nomeado para "Capitania de Sergipe nas Partes do Brasil”, DHBN, 1930, v. 15, p. 378; João Rodrigues Molenar, de 7.10.1636, nomeado para "Capitania de Sergipe no Brasil", DHBN, 1930, v. 16, p. 393; Manoel Pestana de Brito, de 9.3.1654, DHBN, 1936, v. 31, p. 141; Jerônimo de Albuquerque, de 2.9.1656, DHBN, 1930, v. 19, p. 138; Ambrósio Luis de La Penha, de 9.2.1660, DHBN, 1932, v. 21, p. 20, Braz Soares de Passos, de 4.2.1690, DHBN, 1935, v. 30, p. 89; e Sebastião Nunes Colares, de 22.12.1695, DHBN, 1942, v. 57, p. 72; Fernão Lobo de Souza, de 12.6.1703, Arquivo Histórico Ultramarino (AHU), Sergipe, cx. 2, d. 6 e 7; Salvador da Silva Bragança, 18.9.1708, DHBN, 1938, v. 41,p. 230; Antônio Vieira da Fonseca, de 20.6.1711, DHBN, 1943, v. 61, p. 152; Custódio Rabelo Pereira, de 6.6.1719, AHU, Sergipe, cx. 2, d. 25; José Pereira de Araújo, de 17.11.1723, DHBN, 1939, v. 45, p. 143; João da Costa e Silva, de 3.8.1726, AHU, Sergipe, cx. 3, d. 20 e 21; José de Mares Henrique, de 11.3.1754, AHU, Sergipe, cx. 7, d. 25.

${ }^{16}$ DHBN, 1943, v. 60, p. 106. Registro da carta-patente de Jorge de Barros Leite, Lisboa, 25.7.1711; AHU, Sergipe, cx. 8, d. 49. Requerimento de Joaquim José Martins ao príncipe regente solicitando provisão da sua nomeação para o posto de capitão-mor de Sergipe del Rei, em data anterior a 22.11.1796.
} 
Para além das questões militares, governadores e capitães-mores tinham alçada também sobre questões civis e criminais, o que provocava frequentes conflitos de jurisdições com os ouvidores. Nas correspondências dos governadores-gerais/vice-reis com capitães-mores e ouvidores de Sergipe encontram-se orientações sobre produção e comercialização de mercadorias, recolhimento dos tributos e donativos, eliminação de mocambos e de povos originários, dentre outros assuntos. ${ }^{17}$ Vale registrar que divisões bem definidas entre os campos político, jurídico e econômico são próprias das formas estatais contemporâneas, não da Época Moderna. ${ }^{18}$

Não há nas cartas-patentes dos capitães-mores de Sergipe, pelo menos até a nomeação de Manoel Inácio de Morais Mesquita Pimentel, em $1803^{19}$, a indicação de subordinação à "capitania da Bahia”, especificamente. Estava a capitania de Sergipe sujeita ao governo-geral do Estado do Brasil como todas as demais, o que na prática acabava significando a mesma coisa. ${ }^{20}$ Capitania da Bahia e governo-geral, até 1763, confundiam-se numa só entidade, muito embora houvesse diferenças importantes no poder jurisdicional que os governadores-gerais e vice-reis exerciam sobre as capitanias contiguas de Sergipe del Rei, Ilhéus, Porto Seguro e Espírito Santo, territórios sobre os quais a Bahia se projetava, e as capitanias do Norte e do Sul.

Ao assumir o cargo, em 1687, Barros Leite recebeu do Governador Matias da Cunha o Regimento dos capitães-mores. ${ }^{21}$ Dentre as atribuições e limites de jurisdição do cargo, destacase nele a proibição de passarem provisões militares, ofícios da justiça, assim como também

\footnotetext{
17 Ver, por exemplo: instrução passada pelo Castro de Rio Mendonça ao capitão-mor João Munhoz, em 18.7.1671, encarregando-o de fazer guerra aos negros que se encontravam "fugidos nos mocambos", FREEIRE, 2013, p. 229; carta do Marquês de Angeja ao capitão-mor, em 24.1.1715, sobre o envio para Bahia da farinha e feijão, DHBN, 1938, v. 42, p. 223; e outra ao ouvidor, em 27.6.1715, sobre a necessidade de se eliminar um mocambo, DHBN, 1938, v. 42, p. 277; ordem que Vasco Fernandes Cesar de Menezes passou ao capitão-mor Custódio Rabelo Pereira, em 12.12.1720, sobre as caixas de açúcar serem enviadas na forma da lei, DHBN, 1945, v. 69, p. 104; e outra de 25.6.1721, sobre a diligência para prender a negra Jacinta e seu amigo Antônio Dias, acusados de um assassinato, DHBN, 1938, v. 44, p. 66; o capitão-mor interino José Gomes da Cruz informa o governador e capitão-general da Bahia sobre o ataque de índios a uma fazenda, em 9.12.1770, e também à vila de Santo Amaro, em 20.2.1775, Arquivo Público do Estado da Bahia (APEB), Seção de Arquivo Colonial e Provincial - Gov-Geral/Gov. da capitania-mor de Sergipe (1767-1799), mç. 190.

${ }^{18}$ HESPANHA, A. M. Poder e Instituições na Europa do Antigo Regime (coletânea de textos). Lisboa: Fundação Calouste Gulbenkian, 1984, p. 34 e ss. Segundo ele, torna-se impossível localizar nas instituições do Antigo Regime o poder político, ou de uma sociedade política, numa só entidade separada das demais.

${ }^{19}$ Segundo NUNES, M. T. Sergipe colonial II. Rio de Janeiro: Tempo brasileiro, 1996, p. 128, na nomeação régia desse capitão-mor constou: "com subordinação ao Governador e Capitão General da Bahia".

${ }^{20}$ LIMA Jr., 2015, p. 128, chegou a afirmar inclusive que o que se constituiu na Bahia "não era uma Capitania propriamente como as outras, mas a sede do Governo-Geral colonial encarregado da Administração de todo o Brasil".

${ }^{21}$ AHU, Sergipe, cx. 5, d. 2. Cópia do Regimento da Capitania de Sergipe del Rei. Dirigido também às capitanias de Itamaracá, Paraíba, Rio Grande, Ilhéus, Porto Seguro, Espírito Santo, Ilha Grande, São Vicente, e Paranaguá, o documento teve validade longa. Instituído inicialmente pelo vice-rei Conde de Óbidos (1663-1667) - “considerando os grandes inconvenientes que resultavam (...) de os Capitães-Mores das capitanias (...) não terem regimentos (...), mandou passar [este] que universalmente haviam de guardar" -, foi ratificado pelo Governador e Capitão General Afonso Furtado de Castro do Rio de Mendonça (1671-1675) e consta ter servido até pelo menos 1734, quando Francisco da Costa concluiu seu mandato de capitão-mor de Sergipe. Há uma transcrição desse documento em DHBN, 1928, v. 5, pp. 374-380, mas não exatamente igual ao que foi encaminhado para os capitães-mores de Sergipe, indicando que para cada capitania dirigia-se instruções específicas.
} 
cartas de sesmarias, prerrogativas essas dadas aos governadores e capitães-generais. Em seu capítulo $9^{\circ}$, reforçando a centralidade do poder dos governadores-gerais, ordenava que nenhuma capitania do Estado, ou seja, do rei ou de donatário era "subordinada ao governo de outra de que [fosse] vizinha"; e que todas eram "imediatas e sujeitas a este Governo-Geral", com exceção daquelas que expressa e declaradamente registrar o rei "alguma parte de jurisdição deste Governo nos dois regimentos do Governo de Pernambuco e do Rio de Janeiro".

Por determinados períodos no decorrer dos séculos XVII e XVIII, o Estado do Maranhão e o Grão-Pará estiveram fora da jurisdição do governo-geral do Brasil. E as capitanias de Pernambuco e do Rio de Janeiro (mais tarde de São Paulo e de Minas Gerais também) foram instituídas pela coroa com amplos poderes sobre territórios de suas ações e influências, mas continuaram subordinadas ao governador-geral, como mandavam os Regimento de Tomé de Souza (1548) e de Roque da Costa Barreto (1677). ${ }^{22}$ Quando aqueles governadores questionaram essa subordinação, visto que tinham eles também o título de governador e capitão-general, d. João V logo lembrou-os de que seus títulos eram apenas ad honorem, reafirmando o vínculo de subordinação. ${ }^{23}$ Ainda assim, a dupla sujeição - a Bahia e a Lisboa - gerava um espaço de incerteza hierárquica sobre o qual os governadores locais podiam desenvolver um poder autônomo efetivo. ${ }^{24} \mathrm{O}$ certo é que junto com a Bahia, Rio de Janeiro e Pernambuco consolidaram-se, no século XVIII, como importantes centros de poder político e econômico na América portuguesa e no mundo Atlântico.

\footnotetext{
${ }^{22}$ Regimento que levou Tomé de Souza governador do Brasil, Almerim, 17/12/1548. Lisboa, AHU, códice 112, fls. 1-9; e Regimento do governo-geral do Estado do Brasil dado ao Mestre de Campo Roque da Costa Barreto. In: MENDONÇA, M. C. de. Raízes da Formação Administrativa do Brasil - Tomo II - Regimentos XVII a XXXIII. Rio de Janeiro: IHGB; Conselho Federal de Cultura, 1972. Ver capítulo $39^{\circ}$, p. 804. Este Regimento teve validade até pelo menos 1806, quando o comentou o vice-rei d. Fernando José de Portugal e Castro.

${ }^{23}$ RUSSELL-WOOD, A. J. R. "A projeção da Bahia no Império Português”. In: Anais do $4^{o}$ Congresso de História da Bahia. [Salvador 450 anos], 27 de setembro a $1^{\circ}$ de outubro de 1999. Salvador: Instituto Geográfico e Histórico da Bahia; Fundação Gregório de Mato s, 2001 , p. 87. Para estudos específicos sobre os poderes dos governadores-gerais do Brasil, nos séculos XVI e XVII, ver, dentre outros, os trabalhos de COSENTINO, F. C.: Hierarquia política e poder no Estado do Brasil: o governo-geral e as capitanias, 1654-1681. Topoi. Rio de Janeiro, v. 16 , n. 31, p. 515-543, jul/dez., 2015; Governadores gerais do Estado do Brasil (séculos XVI-XVII): ofício, regimentos, governação e trajetórias. São Paulo: Annablume/FAPEMIG, 2009; Construindo o Estado do Brasil: instituições, poderes locais e poderes centrais. In: FRAGOSO, J.; GOUVÊA, M. de F. O Brasil Colonial, 1443-1580. v. I. Rio de Janeiro: Civilização Brasileira, 2014; e de ARAÚJO, H. A. F. F. A construção da governabilidade no Estado do Brasil: perfil social, dinâmicas políticas e redes governativas do governo-geral (1642-1682). (Tese de Doutorado) Universidade Federal do Rio de Janeiro, Instituto de História, Programa de Pós-Graduação em História Social: Rio de Janeiro, 2018.

${ }^{24}$ HeSPAnHA, A. M. As estruturas políticas em Portugal na Época Moderna. In: TENGARRINHA, J. (org). História de Portugal. 2 ed. Bauru, SP: EDUSC, UNESP; Lisboa: Instituto Camões, 2001, p. 134.
} 
Se no século XVI, e mesmo no XVII, Bahia podia significar simplesmente a cidade de Salvador e o recôncavo, no século XVIII, não seria exagero falar de uma "grande Bahia", ou, como a definiu o engenheiro militar José Antônio Caldas, em 1759, da "Potentíssima capitania da Bahia". Incluía ela sob sua jurisdição, ou zonas de influência, as capitanias vizinhas, e, do outro lado do Atlântico, as ilhas de São Tomé e Príncipe e a fortaleza-feitoria de São João Batista de Ajudá, na costa da mina. ${ }^{25}$ A donataria do Espírito Santo foi revertida para a coroa, em 1718, passando a ser uma capitania-mor (similar a Sergipe), vinculada ao Rio de Janeiro na esfera eclesiástica e à Bahia, na civil e militar. As donatarias de Ilhéus e Porto Seguro passaram ambas para a coroa, em 1761, transformando-se em comarcas da Bahia. ${ }^{26}$

O vínculo militar, civil e eclesiástico de Sergipe a Bahia, em princípio, se configurava pela relação de subordinação direta das capitanias ao governo-geral/vice-reinado, como já mencionado. Ocorre que na primeira metade do século XVIII, talvez mesmo antes, os governadores-gerais/vice-reis tomam Sergipe como uma das partes da Bahia. A posição hierárquica inferior, contudo, não impediu certa margem de autonomia política para as capitanias-mores. Lideranças locais reivindicavam maior autonomia e jurisdição, tanto por meios institucionais, fazendo suas súplicas e contestações à coroa portuguesa, quanto por meio de revoltas e motins. ${ }^{27}$ Além disso, o poder dos governadores-gerais/vice-reis não era absoluto sobre elas. Quando João Ribeiro Vila Franca fez petição ao rei d. João IV para confirmação de sua nomeação no cargo de capitão-mor de Sergipe, provido pelo conde de Vila-Pouca de Aguiar, por tempo de seis anos, os conselheiros do rei repreenderam o governador do Brasil para que não fizesse "semelhantes provimentos", muito menos por seis anos, e que se ajustasse "com seu Regimento". 28

\footnotetext{
${ }^{25}$ RUSSELL-WOOD, 2001, p. 86 e ss.; CALDAS, J. A. Notícia Geral de Toda Esta Capitania da Bahia desde o seu descobrimento até o presente ano de 1759. Salvador: Tipografia Beneditina, 1951 [Edição fac-similar], pp. 3 e 477-524.

${ }^{26}$ As donatarias de Paraguaçu (ou do Recôncavo) e de Itaparica e Tamarandiva foram revertidas para a coroa em 1766 e 1793 , respectivamente, fazendo também parte da capitania da Bahia. Cf. BOMFIM, A. G. do. As capitanias de Itaparica e Tamarandiva e do Paraguaçu: administração, direito de propriedade e poder na América Portuguesa (c.1530 - c.1630). Salvador: PPG História da Faculdade de Filosofia e Ciências Humanas da UFBA, 2016; e VARNHAGEN, 1956, T. 4, p. 236.

${ }^{27}$ Dentre os conflitos sociais que marcaram a história de Sergipe, na segunda metade do século XVII e princípio do século seguin te, destacase o motim de 1656. A manutenção das fintas cobradas (em cabeças de gado) pelo governador-geral, o conde de Castelo-Melhor (1650-1654), com o fim de abastecer as tropas na guerra contra os holandeses, provocou insatisfações da elite local. Liderado pelo capitão-mor Manuel Pestana de Brito (1654-1656) e vereadores da câmara de São Cristóvão, os moradores armados expulsaram o vigário-geral da cidade e se voltaram contra o poder do governo-geral do Estado do Brasil. Ver FREIRE, 2013, p. 214-219; e ANTONIO, Edna M. Matos. Correspondências e cultura política na América Portuguesa: cartas e uma rebelião colonial. Revista Brasileira de História da Mídia (RBHM). V. 5, n. 1, jan/2016 - jun/2016.

${ }^{28}$ AHU, Sergipe, cx. 1, d. 3. Consulta do Conselho Ultramarino de 25.8.1651.
} 
Na prática administrativa cotidiana, entretanto, cada vez que os capitães-mores tentaram alargar sua autoridade foram energicamente advertidos pelos governadores-gerais/vice-reis. Em 14 de julho de 1705, Dom Rodrigo da Costa lembrava Fernão Lobo de Sousa, que em outra ocasião já o havia advertido de que se abstivesse de passar patente "de qualquer posto que seja porque não tem jurisdição para isso". ${ }^{29}$ A mesma restrição teve de ser imposta aos capitãesmores Jorge de Barros Leite (em seu segundo mandato, 1712-1714), Antônio Vieira (17141717), Custódio Rebelo Pereira $(1717-1723)^{30}$, Manuel Francês (1745-1748) e Joaquim Antônio Pereira da Serra (1759-1761).

Diante da notícia que Rebelo Pereira havia impedido que um capitão de ordenanças da Vila Nova Real del Rei, com patente confirmada na Bahia, exercesse o seu posto nomeando outro em seu lugar, escreveu o Governador que estranhava "esta resolução tão alheia de quem professa a vida de soldado e não deve desconhecer a razão de súdito". Lembrava ainda a obediência que devia ao "Governador-Geral, e que essa capitania é membro do corpo desta Bahia". ${ }^{31}$ Antes disso, sabendo que exigia na capitania o tratamento de "senhor" o advertiu: "não se deu nunca aos capitães-mores o tratamento de Senhor, e aos Coronéis se tem dado em muitos dos governos dos meus antecessores", e que, "se Vossa Mercê o quer, há de pedi-lo a Sua Majestade, que mandando-o, não só será tratado por senhor Capitão-Mor, mas [receberá], quanto tratamento ele for servido" dar. ${ }^{32}$ Ainda insatisfeito com sua postura, disse-lhe em outra missiva que tinha por ele muita estima e préstimo, e que reconhecia o seu merecimento do cargo. Porém, depois que se viu capitão-mor de Sergipe parecia "que o mesmo Imperador lhe não devia competir". ${ }^{33}$ Não obstante essas queixas, continuou ele no posto por mais quatro anos.

O problema com Manuel Francês é revelador sobre diferenças entre algumas capitaniasmores. Inconformado com a falta de autoridade como capitão-mor de Sergipe, dirigiu carta ao rei alegando que quando exerceu esse mesmo cargo no Ceará (1721-1728) tinha naquele governo quatro livros: um para registro das patentes dos postos da ordenança; outro para as provisões dos ofícios menores das justiças ordinárias; um terceiro para registro das cartas de sesmarias; e um quarto para registros das ordens reais. E provia todos esses postos sem

\footnotetext{
${ }^{29}$ DHBN, 1938, v. 41, p. 89. Carta do governador-geral d. Rodrigo da Costa ao capitão-mor Fernão Lobo de Sousa.

${ }^{30}$ DHBN, 1938, v. 42, pp. 55, 72, 87, 98 e 218; e DHBN, 1946, v. 73, p. 173.

${ }^{31}$ DHBN, 1946, v. 73, p. 74. Carta do conde de Vimieiro ao capitão-mor de Sergipe, em 12.4.1719. Grifo meu.

${ }^{32}$ DHBN, 1939, v. 43, p. 185. Carta do governador-geral ao capitão-mor de Sergipe, em 12.1.1719. Grifo meu.

${ }^{33}$ DHBN, 1946, v. 73, p. 173. Carta do conde de Vimieiro ao capitão-mor de Sergipe, em 6.8.1719.
} 
dependência alguma, pela faculdade que o rei lhe havia concedido. Diante disso, solicitava autoridade para poder também em Sergipe passar as referidas provisões. D. João V pediu parecer ao vice-rei conde de Galveas, que indeferiu a petição. ${ }^{34}$ Aos capitães-mores do Ceará e do Rio Grande concedeu-se, em certos períodos - "atendendo aos longes" da capitania-geral de Pernambuco -, a permissão para passarem provisões. ${ }^{35}$ Concessão essa nunca dada aos capitãesmores de Sergipe del Rei.

A proximidade geográfica foi certamente um fator importante para que a Bahia exercesse com rédeas mais curtas o domínio político sobre Sergipe, mas não o único. Segundo Stuart Schwartz, “a produção açucareira e o dízimo de Sergipe de El-Rey eram geralmente calculados como parte do total baiano. Sergipe era, de fato, uma extensão da economia da Bahia", o que não impediu, por certo, o desenvolvimento histórico diferenciado de um e outro. ${ }^{36}$

Quando em 1763, a cidade de Salvador perdeu a condição de sede do vice-reinado do Estado do Brasil, Sergipe continuou, a partir daí, sob o poder dos governadores e capitãesgenerais da Bahia, dando continuidade a um vínculo político e econômico secular entre os dois estabelecimentos. ${ }^{37} \mathrm{O}$ nível de subordinação, todavia, aumentou. Após a prisão do capitão-mor Joaquim Antônio Pereira da Serra, em 1761, acusado de extorquir "consideráveis somas de dinheiro das pessoas a quem vendia os postos por ele providos em sua particular utilidade", ${ }^{38} \mathrm{o}$ cargo passou a ser ocupado por capitães-mores interinos até 1793, quando da nomeação régia de Valério dos Santos. ${ }^{39}$ Tal condição manteve Sergipe mais vinculado a Bahia do que a Lisboa, como se pode comprovar no próprio fluxo da comunicação política no pós-1763. Dos 392 documentos existentes no Arquivo Histórico Ultramarino referentes à capitania de Sergipe, entre 1705 e 1820, 324 deles (83\%) são dos anos de 1705 a 1762 e apenas 68 (17\%), do período posterior. O Conselho Ultramarino chegou a realizar pelo menos dois concursos para o cargo,

\footnotetext{
${ }^{34}$ AHU, Sergipe, cx. 6, d. 40 e 48. Carta do capitão-mor Manuel Francês ao rei, em 15.4.1745.

${ }^{35}$ Sobre a capitania de Pernambuco e suas anexas ver: CURVELLO, 2019; e CHAVES, J. I. As capitanias de Pernambuco: política e administração na América Portuguesa (sécs. XVII-XVIII). Belo Horizonte: Fino Traço, 2021.

${ }^{36}$ SCHWARTZ, S. Segredos internos: engenhos e escravos na sociedade colonial. São Paulo: Companhia das Letras, 1988, p. 91. Ver também: NUNES, 2006, principalmente os capítulos IV, V e VI.

${ }^{37}$ Não parece correta a interpretação de NUNES, 1996, p. 128, de que a incorporação das capitanias de Sergipe, Ilhéus, Porto Seguro e Espírito Santo por parte da Bahia teria sido uma compensação pela perda da sede do vice-reinado. Como mostrou-se aqui, essas incorporações foram anteriores a 1763 .

38 AHU, Bahia, Coleção Castro e Almeida, cx. 3, d. 5946 e 5947, fl. 3. Traslado das ordens e mais contas pelas quais se mandou pelo Desembargador Joaquim José de Andrade, da Relação desta cidade da Bahia, proceder à devassa sobre os procedimentos de Joaquim Antônio Pereira da Serra Monteiro Correia, capitão-mor que foi da cidade de Sergipe del Rei. Bahia, 18.7.1761. Em 1.7.1766, ele foi inocentado por d. José I, AHU, Sergipe, Cx. 7, d. 48.

${ }^{39}$ NUNES, 1996, p. 128.
} 
em 1767 e 1781, mas, por motivos que se desconhece, os candidatos escolhidos não foram nomeados. ${ }^{40}$

Em instrução passada ao marquês de Valença, em 10 de setembro de 1779, recém nomeado governador e capitão general da Bahia, o Secretário de Estado, Martinho de Melo e Castro, não deixava dúvidas sobre a circunscrição territorial da capitania que ele iria comandar: compreendia ela mais ou menos "250 léguas de costa desde a barra do rio de S. Francisco, que a separa de Pernambuco, até a Capitania do Espírito Santo, que a separa do Rio de Janeiro; e pelo seu interior confina com as Capitanias de Minas Gerais e Goiás." ${ }^{11}$

Mas, se no campo político-institucional a capitania de Sergipe se fragilizava, no campo social e econômico se fortalecia. A população, que em 1707 era de 17.169 pessoas, passou para 54.000, em 1780, e 72.236, em $1808 .{ }^{42} \mathrm{O}$ número de engenhos de açúcar, que em 1730 era de 25, passou para 46, em 1756, e 140, em 1798. ${ }^{43}$ O peso econômico de Sergipe para a Bahia era, com efeito, bastante expressivo, como podemos verificar, por exemplo, na parcela que the coube para a contribuição do donativo do casamento real de d. José com d. Mariana Vitória de Bourbon. Em 1747, a câmara de vereadores de Salvador apresentou ao Conselho Ultramarino a conta do que havia sido pago e do que faltava pagar dos três milhões de cruzados (1.200:000\$000 réis) que, em 1727, se impôs à Bahia e suas anexas. ${ }^{44}$ A distribuição do débito total serve como um índice importante para ilustrar a potencial capacidade econômica de cada uma das partes da capitania. À cidade de Salvador cabia pagar 880:000\$000 réis ${ }^{45}$; à capitania de Sergipe del Rei, 96:000\$000; à vila de Cachoeira e suas anexas (Abadia, Itapicuru e Água Fria), 64:000\$000; à vila de Maragogipe, 28:000\$000; à vila de Santo Amaro da Purificação,

\footnotetext{
${ }^{40}$ AHU, Sergipe, cx. 8, d. 4. Aviso do Secretário de Estado Francisco Xavier de Mendonça Furtado ao Conselho Ultramarino mandand o fixar Editais para o provimento do posto de capitão-mor da capitania de Sergipe del Rei, em 10.1.1767; e AHU, Sergipe, cx. 8, d. 27. Consulta do Conselho Ultramarino referente a nomeação de pessoas para o posto de capitão-mor da capitania de Sergipe del Rei, em 15.2.1781.

${ }^{41}$ Apud VARNHAGEN, 1956, T. IV, p. 291. "Instrução para o marquês de Valença, Governador e Capitão-General da Capitania da Bahia, em 10.9.1779.

42 NUNES, 1996, p. 128 e 129.

${ }^{43}$ MOTT, Luís R. Sergipe del Rei: população, economia e sociedade. Aracaju: FUNDESC, 1986, p. 145-146. Segundo o engenheiro militar CALDAS, 1951, p. 429-438, das 357.316 arrobas de açúcar branco e mascavo que a capitania da Bahia produzia em 1759,61.228 (17\%) eram produzidas em Sergipe. Conforme SCHWARTZ, 1988, p. 90-92, a produção açucareira proveniente de Sergipe era muito mais importante quantitativamente do que de Ilhéus e Porto Seguro. "No início do século XIX - diz esse historiador -, foram arrolados 163 engenhos em Sergipe de El-Rey, e sua produção perfazia cerca de $25 \%$ do total baiano".

${ }^{44}$ AHU, Bahia, avulsos, cx. 89, d. 7250. "Conta do donativo real de três milhões que se impuseram à capitania da Bahia e suas an exas extraída dos livros de receita e recebimentos dos tesoureiros, a multa que tocou a cada uma das vilas da comarca desta cidade e capitanias anexas a esta capital, o que tem pago e o que restam até o presente mês de março de 1747.” A conta aparece também em AHU, Bahia, Castro e A lmeida, cx. 5, d. 712. Ofício do vice-rei Conde de Atouguia para Diogo de Mendonça Corte Real, em 10.9.1753, acerca do Donativo imposto pela carta régia de 6.4.1727 para pagamento de despesas com o casamento dos príncipes.

${ }^{45}$ Entrava nesse débito, além da contribuição dos particulares, parcelas lançadas nas transações do azeite das baleias, da aguardente da terra, dos escravos da Costa da Mina e do gado do açougue.
} 
32:000\$000; à vila de Sergipe do Conde, 24:000\$000; à vila de Jaguaripe, 12:000\$000; à vila de Camamu, 14:000\$000; à vila de Cairu, 6:000\$000; à vila de Boipeba, 2:000\$000; à vila de Jacobina, 16:000\$000; à vila do Rio das Contas, 12:000\$000; à capitania dos Ilhéus, 6:000\$000; à capitania de Porto Seguro, 4:000\$000; e à capitania do Espírito Santo, 4:000\$000.

Com os donativos e com os dízimos, com o fornecimento do açúcar, do tabaco, do gado, da farinha de mandioca e de outros produtos mais a capitania de Sergipe del Rei foi fundamental nos negócios da Bahia, motivo pelo qual seus governadores, vice-reis e capitães-generais procuraram mantê-la sob apertado controle político. Contudo, o crescimento econômico e o fortalecimento de grupos locais, em meio ao processo que levaria a independência do Brasil, abriram caminho para a separação da capitania de Sergipe da Bahia, efetivada num intrincado processo político de idas e vindas entre 1820 e $1822 .^{46}$

\section{O GOVERNO DA ILHA DE SANTA CATARINA: ESTATUTO E CONDICÃO DE SUBALTERNIDADE}

Distintamente da capitania de Sergipe del Rei e de outras no Norte, estabelecidas no primeiro século da colonização, o governo da ilha de Santa Catarina teve início somente a partir da terceira década do século XVIII. Muito antes disso, no entanto, incursões dos paulistas em busca de metais preciosos e captura dos índios, além de padres e mercadores, ${ }^{47}$ avançaram pelos sertões meridionais transformando os espaços, com consequências irreversíveis aos povos originários, dentre as quais a sua dramática redução demográfica.

A um fator de ordem econômica a justificar essa "tardia integração", deve se acrescentar outro de natureza político-diplomática: como resultado da própria convergência dos domínios ibéricos ao mesmo espaço e, por conseguinte, da hesitação de ambos sobre quais seriam seus limites nele, retardando assim um processo de ocupação formal. Constituiu-se ali uma ampla

\footnotetext{
${ }^{46}$ Sobre o tema ver, sobretudo, ANTÔNIO, E. M. M. A Independência do solo que habitamos: poder, autonomia e cultura política na construção do Império Brasileiro. Sergipe (1750-1831). São Paulo: Editora UNESP, 2012.

${ }^{47}$ Sem falar nos empreendimentos espanhóis com a fundação das missões jesuíticas e da existência efêmera de Ontiveros, Ciudad Real e Vila Rica. Ver ALMEIDA, L. F. de. A diplomacia portuguesa e os limites meridionais do Brasil (1493-1700). Coimbra: Universidade de Coimbra, 1957 (v. I), p. 93.
} 
zona de fronteira, exigindo cautela por parte das cortes de Portugal e da Espanha nas políticas de expansão de seus domínios.

Todas as tentativas de colonização das terras ao sul de São Vicente pelo sistema das capitanias hereditárias não se efetivaram. Pero Lopes de Sousa (1497-1539) morreu antes de tomar posse das "terras de Santana”. Salvador Correia de Sá e Benevides (1602-1686), governador do Rio de Janeiro (1637, 1647-48 e 1658) e um dos principais armadores da base mercantil formada pelo triângulo Rio de Janeiro-Luanda-Buenos Aires, buscou receber por mercê uma donataria "de 100 léguas de costa" para si e seus herdeiros, "nas terras onde chamam a ilha de Santa Catarina", metade para a banda do norte, metade para a banda do sul. Rejeitada duas vezes no Conselho Ultramarino, em 1646 e 1658, a petição foi concedida em 1676, em nome do seu filho e de seu neto, que não chegaram a se instalar. ${ }^{48}$

Num movimento de fixação a terra, grupos de sertanistas, muitos deles já miscigenados com os índios, vão dar origem aos povoados de São Francisco do Sul (c. 1658), Curitiba (c. 1668), Laguna (c. 1674) e N. Sra. do Desterro, na ilha de Santa Catarina (c. 1690). ${ }^{49}$ As minas descobertas (e a descobrir) no sertão, o gado solto pelos campos, as madeiras, a erva-mate, a mão de obra indígena, o comércio no rio da Prata e tantos outros recursos que aquelas terras e mares poderiam fornecer aos mercadores explica a crescente valorização desse espaço ${ }^{50}$ nas décadas seguintes. A ilha de Santa Catarina não só fez parte dessa "nova geografia sulatlântica", na expressão de Luiz Felipe de Alencastro ${ }^{51}$, como ocupou posição estratégica militar fundamental para sua defesa e domínio.

\footnotetext{
${ }^{48}$ Anais da Biblioteca Nacional do Rio de Janeiro, v. XXXIX, pp. 80, 99 e 142. Consultas do Conselho Ultramarino. Salvador de Sá defendeu a implantação de uma Repartição do Sul separada do governo-geral da Bahia. A divisão - mais teórica do que prática - aparece também nos governos do Rio de Janeiro de Antônio Salema (1574-78) e Francisco de Sousa (1608-12). Sobre isso ver: BOXER, C. Salvador de Sá e a luta pelo Brasil e Angola, 1602-1686. Trad. Olivério de Oliveira Pinto. São Paulo: Ed. Nacional: EDUSP, 1973 (Brasiliana, v. 353 ), p. 306 ; e RIBEIRO, M. da S. Divisão Governativa do Estado do Brasil e a Repartição do Sul. XII Encontro Regional de História - ANPUH, Rio de Janeiro, 2006.

${ }^{49}$ Considerado como um dos fundadores do povoado de N. Sra. do Desterro, Francisco Dias Velho chegou à ilha de Santa Catarina com sua família, agregados, dois padres e 500 índios “domesticados”. Cf. CORREA, C. H. P. História de Florianópolis - ilustrada. Florianópolis: Insular, 2004, p. 40.

${ }^{50}$ Sobre a ideia de "valorização do espaço" como base para construção dos territórios ver: MORAES, A. C. R. Bases da formação territorial do Brasil: o território colonial brasileiro no "longo" século XVI. São Paulo: Hucitec, 2000 (Introdução); e MORAES, A. C. R.; COSTA, W . M. da. A valorização do espaço. São Paulo: Hucitec, 1984.

${ }^{51}$ ALENCASTRO, L. F. de. O trato dos viventes: formação do Brasil no Atlântico Sul, século XVI e XVII. São Paulo: Companhia das Letras, 2000, p. 199.
} 
O último a solicitar o "senhorio e propriedade" da ilha foi o ex-governador da Colônia do Sacramento, Sebastião da Veiga Cabral, em 1717. ${ }^{52}$ Nesse momento, porém, a coroa já demostrava claro propósito em administrar essas conquistas meridionais sem intermediários, negando o pedido. Seis anos antes havia reincorporado ao patrimônio régio a capitania de São Vicente, fazendo o mesmo, dez anos depois, com a donataria do filho e neto de Salvador de Sá. A partir de 1727, portanto, toda a costa atlântica, do Rio de Janeiro ao rio da Prata, estava sob o controle oficial da coroa portuguesa.

Medidas mais concretas de consolidação do domínio luso ali vieram após o "grande sítio" imposto pelos espanhóis à Colônia do Sacramento (1735-1737). Em 1736, uma expedição comandada pelo brigadeiro José da Silva Paes procurou romper com o bloqueio da Colônia, desalojar os espanhóis de Montevidéu e fundar uma fortaleza na barra sul do Rio Grande. Realizada essa missão (à exceção da tomada de Montevidéu, que fracassou), Silva Paes rumou para a ilha de Santa Catarina seguindo orientações da carta régia de 11 de agosto de 1738, enviada por Gomes Freire de Andrade.

A ordem era que erguesse na ilha uma fortificação, e que do Rio de Janeiro deveriam sair todos os "socorros e ordens" necessárias "para defesa da Nova Colônia e ajuda do novo estabelecimento do Rio Grande de São Pedro"; definia que ficassem "todos os portos e lugares da marinha debaixo de um só mando", separado de São Paulo e unido ao do Rio de Janeiro.

Informava ainda que "as Minas dos Goyazes, Cuyaba e mais descobertos" deviam ter um govenador particular, ficando subordinado a Minas Gerais. ${ }^{53}$ Reordenamento político que evidencia a percepção da monarquia desse amplo perímetro espacial, formado por Rio de Janeiro, Goiás, Cuiabá, São Paulo, Rio Grande de São Pedro, Colônia do Sacramento e ilha de Santa Catarina, como um todo articulado.

Considerada por muitos historiadores como a certidão de nascimento da "capitania subalterna de Santa Catarina" 54 , não há nessa carta régia menção ao termo "capitania" e

\footnotetext{
${ }^{52}$ Arquivo do Estado de São Paulo. Documentos Interessantes para a história e costumes de São Paulo, v. XVIII, p. 8 e 9. Carta de d. João V ao governador da praça de Santos, em 11.3.1717.

${ }^{53}$ Revista do Instituto Histórico e Geográfico do Rio Grande do Sul , 1948, n. 109 a 112. Documentos sobre a Colônia do Sacramen to e expedição que a foi socorrer em 1736, p. 132.

54 Além dos autores mencionados na nota 8, consta também em: PIAZZA, W. F. Santa Catarina: sua história. Florianópolis: Ed. UFSC; Lunardelli, 1983, p 119; e CABRAL, O. R. Santa Catarina (História - evolução). São Paulo: Companhia Editora Nacional, 1937 (Col. Brasiliana, v. 80), p. 81. Alguns cronistas e historiadores do século XIX, todavia, classificaram aquele ato régio como dando origem a um "governo separado", ou "subgovernadoria". São eles: PAIVA, J. G. de O. Notícia geral da Província de Santa Catarina. In: DICIONÁRIO
} 
tampouco esse termo seria utilizado para nominar essa colônia nas duas décadas seguintes. O que se implantou na ilha, em 1738, foi um "governo", uma "praça militar" e assim denominavam as autoridades de ambos os lados do Atlântico. A nomeação régia dos seus governadores seguiu a forma: "Hey por bem nomeá-lo Governador da Ilha de Santa Catarina por tempo de três anos, e o mais que eu for servido enquanto lhe não mandar sucessor". ${ }^{55} \mathrm{~A}$ patente militar que a maioria deles tinha, ou alcançava, no momento das nomeações era de coronel de infantaria. Quando ocorria de entrarem no posto com uma patente inferior, logo suplicavam pela promoção. Assim procederam o sargento-mor José Pereira Pinto (1786-1791) e o tenente-coronel João Alberto de Miranda Ribeiro (1793-1800). ${ }^{56}$

Com a ampliação do corpo político da ilha ao continente (as vilas de Laguna e de São Francisco do Sul passaram para sua jurisdição em 1742 e 1750, respectivamente) constata-se que, ao lado das denominações de "governo", "praça militar", ou "distrito", da capitania do Rio de Janeiro, começa a ser usual, a partir da década de 1760, sobretudo, por parte das autoridades locais (governadores, escrivães, provedores, oficiais da câmara), a utilização do termo "capitania". Primeiro, "capitania da Ilha de Santa Catarina", depois, suprimindo-se o designativo insular. Como "Escrivão da Fazenda Real e Matrícula da Gente de Guerra nesta Capitania da Ilha de Santa Catarina", se colocava Domingos Gomes Dias, ${ }^{.7}$ "Mapa do Batalhão de Marim e de toda a Guarnição desta Capitania...” era o cabeçalho de um quadro com o número dos oficiais e soldados de Santa Catarina assinado pelo seu governador Francisco de Souza de Menezes, em 30 de novembro de $1773 ;{ }^{58}$ da mesma forma apresentava seu relatório o provedor, em 31 de dezembro de 1780: "Conta Corrente da Entrada e Saída de todo o dinheiro, que entrou nos Cofres da Provedoria da Real Fazenda da Capitania de Santa Catarina...".59 O

\footnotetext{
topográfico, histórico e estatístico da Província de Santa Catarina. Florianópolis: IHGSC, 2003 (Col. Catariniana, 5), p. 33. [1. ed. 1868]; COELHO, M. J. d'A. Memória histórica da Província de Santa Catarina. 2. ed. Desterro: Tip. J. J. Lopes, 1877, p. 25. [1. ed. 1853]; PINHEIRO, J. F. F. (Visconde de São Leopoldo). Resumo histórico da Província de Santa Catarina. Anais da Província de São Pedro. Porto Alegre: Mercado Aberto, 1982 (Série Documenta, 11), p. 223. [1. ed. c. 1832]; e HANDELMANN, H. História do Brasil. 4. ed. São Paulo: Itatiaia, 1982, p. 36. [1. ed. alemã: 1860].

${ }^{55}$ Cf. SILVA, A. da. O governo da ilha de Santa Catarina e sua terra firme: território, administração e sociedade (1738-1807). Rio de Janeiro: Arquivo Nacional, 2013, p. 64. (Grifo meu)

56 AHU, Santa Catarina, cx. 4, d. 329. Carta de José Pereira Pinto a Martinho de Melo e Castro, secretário de Estado dos Negócios Ultramarinos, em 20.3.1789; AHU, Santa Catarina, cx. 5., 373. Carta de João Alberto de Miranda Ribeiro a Luís Pinto de Souza Coutinho, secretário de Estado dos Negócios Ultramarinos, em 24.5.1796.

${ }^{57}$ AHU, Santa Catarina, cx. 3, d. 225. Conta da despesa da Fazenda Real Para o Real Erário, 1763. (Grifo meu)

58 ANRJ, Cód. 106, v. 02, fl. 211. (Grifo meu)

${ }^{59}$ ANRJ, Cód. 106, v. 03 (final). (Grifo meu)
} 
vice-rei Marquês do Lavradio, em seu Relatório de 1779, também refere-se a esse estabelecimento como capitania. ${ }^{60}$

Não houve para os governos subalternos do Rio de Janeiro um regimento único de modo a regulamentar o cargo tal qual existiu para os capitães-mores. Na ilha de Santa Catarina, dizia o governador João Alberto de Miranda Ribeiro ao Conselho Ultramarino, em 1797, encontravam-se somente "algumas régias ordens vagas, que para diferentes objetos foram aos mesmos governadores remetidas". ${ }^{61}$ Pode-se, todavia, depreender as atribuições e os limites de poder deles examinando as correspondências ativas e passivas com as autoridades superiores. As guerras abertas - ou a eminência de nelas entrar - contra os espanhóis colocavam as questões militares sempre em primeiro plano nas orientações passadas a esses governadores. Mas tal qual os capitães-mores de Sergipe, tinham de promover o desenvolvimento econômico do estabelecimento, e não faltaram orientações nesse sentido. ${ }^{62}$ As atribuições e os limites jurisdicionais de poder de uns e outros foram praticamente os mesmos. Estavam também proibidos de passar provisões militares, ofícios civis e de concederam cartas de sesmarias. Todavia, a provisão de 9 de agosto de 1747, autorizava os governadores da ilha de Santa Catarina (assim como os do Rio Grande de São Pedro) a fazerem concessões de um quarto de légua em quadro aos casais das ilhas de Açores e da Madeira. ${ }^{63}$ Essa disposição legal acabou por provocar confusões com os governadores seguintes que doavam os pequenos lotes (as datas de terras) com o nome de sesmarias, sendo sempre repreendidos pelos vice-reis.

Recorrentes foram as súplicas dos governadores para que se desse autonomia a essa unidade política, equiparando-a as demais capitanias-gerais do Brasil. José da Silva Paes, seu primeiro governador, argumentava ao rei que a "experiência tem mostrado que as subordinações dos governos uns aos outros não só são prejudiciais aos povos, senão também

\footnotetext{
${ }^{60}$ Relatório do Marquês de Lavradio, apresentado ao Vice-Rei Luis de Vasconcelos e Sousa seu sucessor, em 19 de junho de 1779 , in CARNAXIDE, V. de. O Brasil na administração pombalina: economia e política externa. Rio de Janeiro: Companhia Editora Nacional, 1940, p. 329.

${ }^{61}$ AHU, Santa Catarina, cx. 6, d. 386. Relatório do governador João Alberto de Miranda Ribeiro ao Conselho Ultramarino, em 16.11.1797. Informação ratificada por BRITO, P. J. M. de. Memória política sobre a capitania de Santa Catarina. Lisboa, 1829 [1816], p. 45-46. “O Governador não tem regimento privativo, que regule as suas atribuições; dirige-se pelas leis e regulamentos tanto militares como civis relativamente aos casos gerais, e pelas ordens, que pela diuturnidade dos tempos, e sucessão dos acontecimentos tem sido expedidas aos diferentes Governadores da Capitania em diversas épocas: não tem autoridade alguma na administração da Fazenda Real, da justiça civil e criminal, e nos objetos municipais, nem pode ingerir-se nestas diferentes administrações, sem que para isso receba ordens do Ministério."

62 SILVA, 2013, p. 149-161 e 178-187.

${ }^{63}$ PIAZZA, W. F. A epopéia açórico-madeirense (1747-1756). Florianópolis: EdUFSC; Lunardelli, 1992 , p. 87.
} 
ao serviço de V.M.". ${ }^{64}$ Desejava ele erguer na ilha um estabelecimento subordinado apenas ao vice-rei (naquele momento sediado na Bahia), como estavam todos os capitães-generais do Brasil. Ocorre que quando a sede do vice-reinado passou para o Rio de Janeiro, em 1763, o poder que os vice-reis passaram a exercer sobre os governadores subalternos do Sul foi superior ao poder que sobre eles exercia o governador e capitão-general Gomes Freire de Andrade. ${ }^{65}$ Uma das motivações para a transferência da capital se assentava justamente na ampliação do controle e defesa daqueles territórios meridionais.

De acordo com o secretário de ordens da ilha, Paulo J. Miguel de Brito, a partir de 1763, todas as arrematações das rendas daquele governo eram feitas perante a Junta da Fazenda do Rio de Janeiro, que também recebia os rendimentos da capitania. ${ }^{66}$ No final do século, João Alberto de Miranda Ribeiro reclamava à rainha que todas as decisões políticas, militares e econômicas da ilha deviam passar pelo vice-rei do Estado do Brasil, ficando "o governador de uma tão considerável capitania" sem autoridade alguma. "Que importa ser governador, e que este cheio de fadigas anime o comércio, instrua e promova a agricultura, e discipline as tropas, se uns e outros conhecem por experiência, que nas mãos do governador não existe autoridade necessária!” Seria bom, argumentava ele, que o governo desta capitania não tivesse dependência do Rio de Janeiro, "tornando os Governadores a dirigirem as suas contas diretamente para a Corte, como se praticou até ao tempo em que governou Dom José de Melo Manoel" (1753-1762). ${ }^{67}$

Tais súplicas não só não foram atendidas como se reduziu ainda mais o poder dos seus governadores. Em 1807, ao elevar o governo subalterno do Rio Grande de São Pedro à capitania-geral, d. João estabeleceu que os limites dela compreenderiam "todo o continente ao sul da capitania de São Paulo e as Ilhas adjacentes", ficando-lhe "subordinado o governo da Ilha de Santa Catarina". ${ }^{68}$ A ideia era de que a ilha servisse como um porto de "depósito ou interposto do comércio" da nova capitania.

\footnotetext{
${ }^{64}$ Revista do Instituto Histórico e Geográfico do Rio Grande do Sul, n. 109 a 112, pp. 135-36. Ofício de José da Silva Paes a d. João V, em 20.6.1739.

65 Ver mais em SILVA, 2013, p. 121 e ss.

${ }^{66}$ BRITO, 1829, p. 68.

${ }^{67}$ AHU, Santa Catarina, cx. 6, d. 386. Relatório do governador João Alberto de Miranda Ribeiro à rainha d. Maria I, em 16.11.1797. (grifo meu)

68 Arquivo Nacional da Torre do Tombo (ANTT), Chancelaria de D. Maria I, Lv. 78, fl. 181v, Carta Patente de nomeação de d. Diogo de Souza, em 25.02.1807. (Grifo meu)
} 
Dois anos depois, no entanto, diante das "presentes circunstâncias", o príncipe regente, já estabelecido no Rio de Janeiro com sua corte, revogou essa subordinação. Explicava ele a Diogo de Souza que, por ter a ilha de Santa Catarina "posição local e situação geográfica" da maior importância, ficasse ela independente e sujeita às ordens imediatamente por ele expedidas. ${ }^{69}$ As circunstâncias a que d. João se referia tinha que ver com a crise política e diplomática resultantes da deposição do rei espanhol por Napoleão Bonaparte. Ela reascendia as pretensões lusas - muito acalentadas pela princesa Carlota Joaquina, irmã do rei deposto, Fernando VII - de expansão de suas fronteiras até o estuário platino. Na primeira intervenção (1811-12), fracassada, e na seguinte (1816-21), vitoriosa, resultando na incorporação da banda oriental do Uruguai como província Cisplatina, a ilha serviu de base de apoio para as tropas luso-brasileiras. Santa Catarina só se equipararia institucionalmente às demais unidades políticas do império com o decreto das Cortes Gerais de Lisboa de 28 de fevereiro de 1821, quando todas as capitanias e governos subalternos passaram a ser províncias do Reino Unido de Portugal, Brasil e Algarves.

A principal função do governo da ilha de Santa Catarina foi de servir de base militar para defesa desse amplo território entre a capitania de São Paulo e o rio da Prata. Mas não se restringia a isso. Estava ela mesma diretamente vinculada aos interesses mercantis de ambos os lados do Atlântico através do fornecimento do azeite de baleia, da arrematação dos contratos dessa pesca e do dízimo, do recolhimento dos donativos reais e do abastecimento de alimentos, principalmente, de farinha de mandioca.

\section{SOLDOS E OUTROS RENDIMENTOS}

Os perfis desses agentes coloniais - estatuto social, graduação militar e soldo que auferiam no exercício do cargo - servem como índices importantes de identificação dos estabelecimentos na hierarquia política do império português.

Por serem os governadores coronéis, eram chamados de "Senhor", ou "Senhor Coronel Governador", tratamento superior ao "Vossa Mercê" conferido aos capitães-mores. Distinção

${ }^{69}$ Carta régia de 14 de abril de 1809. Coleção de Leis do Império do Brasil, 1809, v. 1, p. 40. 
que nos dois casos aqui analisados se materializava também no soldo que recebiam. Enquanto os governadores de Santa Catarina mantiveram no período de 1749 a 1817 , o valor anual de 2:000\$000 réis, ${ }^{70}$ os capitães-mores de Sergipe auferiram importâncias menores. Custódio Rabelo Pereira em petição ao rei de 1718 , solicitou aumento para $300 \$ 000$ réis ao ano (o mesmo que recebiam os capitães-mores do Espírito Santo), alegando que não podia se "sustentar, vestir e pagar casa de aluguel" com os $100 \$ 000$ réis que auferia no cargo. ${ }^{71}$ Teve parecer favorável do Conselho Ultramarino. ${ }^{72}$ Francisco da Costa (1732-1736), em requerimento ao rei, dizia que até o tempo de José Pereira Araújo (1722-1726), de modo a complementar seus diminutos soldos, os capitães-mores cobravam uma ou mais patacas ${ }^{73}$ como propinas dos soldados nas mostras das companhias de ordenanças. Como essa prática foi logo depois proibida por ordem régia, pedia para que autorizasse o senado da câmara de São Cristóvão a pagar o aluguel de sua morada, como fazia com o ouvidor-geral. ${ }^{74}$ Em 1759, enquanto o vice-rei conde dos Arcos recebia anualmente 4:800\$000 réis, Joaquim Antônio Pereira da Serra ganhava em Sergipe $500 \$ 000$ réis. $^{75}$ Os capitães-mores que se seguiram, na condição de interinos, ganhavam valores mais modestos. José Gomes da Cruz, em 26 de setembro de 1767, pedia ao vice-rei conde de Azambuja equiparação ao soldo de Pereira da Serra, por não conseguir se sustentar no cargo com o que ganhava como tenente. ${ }^{76}$

Os títulos nobiliárquicos podiam também render gratificações. Tanto os governadores de Santa Catarina quanto os capitães-mores de Sergipe provinham do grande e impreciso grupo da chamada "nobreza simples", ou até de origens mais humildes, alcançando ao longo de suas carreiras certa distinção honorífica por meio dos serviços prestados nas conquistas. ${ }^{77}$ Alguns

\footnotetext{
${ }^{70}$ Cf. SILVA, 2013, p. 91. Exceção a essa regra foi João Alberto de Miranda Ribeiro (1793-1800), que por não conseguir a promoção que pleiteava de tenente-coronel a coronel, manteve o soldo de 1:200\$000 réis anuais.

${ }^{71} \mathrm{Na}$ segunda metade do século XVII, eles auferiam $100 \$ 000$ réis de soldo ao ano. Cf. SIQUEIRA, L. Homens de mando e de guerra: capitãesmores em Sergipe del Rey (1648-1743). Salvador: PPG História Social da Faculdade de Filosofia e Ciências Humanas da UFBA (Tese de Doutorado), 2016, p. 19.

${ }^{72}$ AHU, Sergipe, cx. 2, d. 108. Consulta ao Conselho Ultramarino, em 1.2.1719.

${ }^{73}$ Moeda de prata no valor de $\$ 320$ réis.

${ }^{74}$ AHU, Sergipe, cx. 6, d. 9. Requerimento de Francisco da Costa ao rei, em 22.11.1740.

75 CALDAS, 1951 , p. 349 e 457

76 APEB, Seção de Arquivos Colonial e Provincial. Gov-Geral/Gov. da Capitania - Capitão-Mor de Sergipe, 1767-1789, mç. 190. Segundo CALDAS, 1951, p. 347, o tenente destacado na fortaleza de São João Batista de Ajudá, na Costa da Mina, auferia em 1759, $200 \$ 000$ réis por ano.

77 Ver CUNHA, M. S. da.; MONTEIRO, N. G. Governadores e capitães-mores do império atlântico português nos séculos XVII e XVIII. In: MONTEIRO, N. G.; CARDIM, P.; CUNHA, M. S. da. (org). Optima Pars: elites ibero-americanas do Antigo Regime. Lisboa: Imprensa de Ciências Sociais, 2005, pp. 214, 225 e 251; MONTEIRO, N. G. Elites e poder: entre o Antigo Regime e o liberalismo. Lisboa: ICS, 2003, pp. 144-45; MONTEIRO, N. G. Governadores e capitães-mores do império atlântico português no século XVIII. In: BICALHO, M. F. B.; FERLINI, V. (orgs). Modos de governar: ideias e práticas políticas no império português - séculos XVI a XIX. São Paulo: Alameda, 2005, pp. 98 e ss.
} 
em posições de maior privilégio: fidalgos de nascimento. O capitão-mor de Sergipe, José Pereira Araújo, por exemplo, tinha o foro de escudeiro-fidalgo com $\$ 700$ réis de moradia mensal. Solicitou também o Hábito de Cristo e $60 \$ 000$ réis de tença por ano. ${ }^{78}$ Joaquim Antônio Pereira da Serra era um fidalgo-cavalheiro com brasão de armas. Obteve o Hábito da Ordem de Cristo, mais $12 \$ 000$ réis de tença anual. ${ }^{79}$ Casos semelhantes encontramos também entre os governadores de Santa Catarina. ${ }^{80}$

Ganhos financeiros maiores podiam advir dos negócios lícitos e ilícitos praticados por esses agentes localmente. Vimos que Pereira de Serra foi acusado de extorquir dinheiro das pessoas a quem vendia postos por ele providos em Sergipe. Embora absolvido da culpa, a prática não devia ser estranha na capitania.

No caso da ilha de Santa Catarina, o movimento comercial do seu porto constituía uma grande fonte de recursos, e certos governadores souberam tirar proveito pessoal disso. Em passagem pela ilha, em 1740, o viajante inglês George Anson, relatou em seu diário o que para ele seria a "conduta indigna" do governador José da Silva Paes: "ele se veste melhor, vive mais magnificamente, conhece melhor o valor do dinheiro do qual os habitantes jamais sonharam, empregando meios para enriquecer que os outros também nunca tiveram a menor ideia. [...] Pela proximidade do rio da Prata", ele fazia "um bom comércio de contrabando entre os portugueses e os espanhóis", trocando o ouro pela prata, o que prejudicava "o rendimento dos dois reis, que ficavam privados do seu quinto". ${ }^{81}$

Há que se considerar ainda que, mesmo que reinóis de nascimento, capitães-mores e governadores podiam estabelecer vínculos familiares e patrimoniais sólidos nos territórios para os quais eram destacados, deixando-os mais no interior da sociedade local. Jerônimo de Albuquerque, tendo sido nomeado capitão-mor de Sergipe por dois anos (1657-1658), fez petição ao rei solicitando sua manutenção no cargo por seis ou ao menos cinco anos, alegando ser "um fidalgo velho e de muitos serviços, casado com mulher e filhos e fazenda que perdeu com a guerra [contra os holandeses] daquelas capitanias". 82

\footnotetext{
78 ANTT, Registro Geral de Mercês, D. João V, Lv. 3, f. 128 e Lv. 14, f. 353; AHU, Sergipe, cx. 2, d. 43.

${ }^{79}$ ANTT, Registro Geral de Mercês, D. José I, Lv. 8, f. 224.

${ }^{80}$ SILVA, 2013, p. 83 e ss.

${ }^{81}$ ANSON, G. Apud HARO, M. A. P. de (org). Ilha de Santa Catarina: relatos de viajantes estrangeiros nos séculos XVIII e XIX. 3 ed. Florianópolis: EdUFSC; Lunardelli, 1990, p. 66.

${ }^{82}$ AHU, Sergipe, cx. 1, d. 4. Consulta do Conselho Ultramarino referente a pedido de Jerônimo de Albuquerque, em 16.6.1655.
} 


\section{ÓRGÃOS DA ADMINISTRACÃO CIVIL E MILITAR}

Constata-se na comparação dos dois estabelecimentos diferenças na administração militar, judicial e fazendária. ${ }^{83} \mathrm{Em}$ ambos, a formação de um corpo militar serviu de base para a organização dos sistemas produtivos e tributários, mas tiveram dimensões distintas. Em Sergipe, no século XVIII, a guarnição de $1^{a}$ linha (as tropas pagas) era formada por 1 capitãomor, 1 sargento-mor, 1 ajudante e 30 soldados do regimento de infantaria destacados da Bahia, como mostram o mapa apresentado pelo capitão-mor José Mares Henriques de 1757, e a Notícia geral... de José Antônio Caldas de $1759 .{ }^{84}$ Regimento esse nem sempre completo. Em carta ao rei, de 3 de agosto de 1724, o ouvidor-geral dizia "que há anos se não socorre esta praça [de Sergipe] com soldados, pois nela se acham oito ou nove, e alguns deles quase incapazes por terem aqui envelhecido". ${ }^{85}$ Esse não era um problema exclusivo de Sergipe. As baixas por morte, deserção e invalidez costumavam ser informadas pelos capitães-mores e governadores nas listas. Completo ou não, tudo indica que o contingente militar de Sergipe nunca tenha ultrapassado os 30 soldados, sobretudo, no tempo dos capitães-mores interinos (1761-1793). Importante destacar que a sua força militar, assim como nos demais estabelecimentos da América portuguesa, não se restringia aos soldados de $1^{\mathrm{a}}$ linha. Havia ainda as tropas de auxiliares (2 $2^{\mathrm{a}}$ linha), também chamadas de milícias, organizadas em terços, e os corpos de ordenanças ( $3^{\mathrm{a}}$ linha), organizados em companhias, ambas sem soldo. Essas últimas, recrutadas entre a população civil masculina em idade de portar armas.

Bem mais robusto foi o aparelho militar montado nos governos subalternos do Rio de Janeiro. Entre 1739 e 1800, quatro fortalezas e pelo menos outros sete fortes menores foram erguidos na ilha de Santa Catarina e no seu entorno, compondo um dos mais expressivos sistemas de fortificações portuguesas do século XVIII. Em tempos de paz, como em 1782, o Regimento de infantaria das tropas pagas da ilha era de 800 praças, mais 21 oficiais superiores. ${ }^{86}$ Em 1796, chegou a 1.027 homens, representando 4,12\% da população total de

\footnotetext{
${ }^{83}$ Não se abordará aqui a estrutura interna desses órgãos, com seus diferentes cargos e funções. Questões, por certo, importantes para a análise comparativa, mas que demandam outra investigação.

${ }^{84}$ AHU, Sergipe, cx. 7, d. 36. Mapa de Infantaria por destacamento da cidade de Sergipe del Rei, em 23.11.1757; CALDAS, 1951, p. 228 e 471 .

${ }^{85}$ AHU, Sergipe, cx. 2, d. 66. Carta do ouvidor-geral, Antônio Soares Pinto, a d. João V.

${ }^{86}$ ANRJ Fundo 86, cód. 106, v. 4. Mapa do mês de julho de 1782 do Regimento de Infantaria da Capitania da Ilha de Santa Catarina em $1^{\circ}$ de Agosto.
} 
24.892 habitantes. ${ }^{87}$ Em tempos de guerra, como nas vésperas da invasão espanhola de 1777 , ou nas campanhas da cisplatina (1811-1812 e 1816-1821), o contingente militar era muito superior, com guarnições vindas de outras partes do Brasil. Em Sergipe, os 30 soldados não chegavam a ter significância relativa no cômputo geral da população que, em 1802, somava 55.668 habitantes. ${ }^{88}$

Na esfera da administração judicial e fazendária observa-se também uma diferença importante. Em 1696, d. Pedro II mandou criar dois novos "lugares de letras": um de ouvidor e provedor da comarca de Sergipe del Rei; outro de ouvidor e provedor da comarca da Bahia, "cada qual com duzentos mil réis de ordenado cada ano". ${ }^{89}$ Diante da documentação analisada, é possível verificar a inexistência de um cargo separado de provedor-mor em Sergipe. Junto às atribuições judiciárias o ouvidor-geral agregava a de provedor das fazendas, mas restrito a administração dos bens de "defuntos e ausentes, resíduos e capelas". O controle das receitas e despesas mais relevantes da capitania - arrematação dos contratos do dízimo, recolhimento dos donativos reais, pagamento das folhas civil, militar e eclesiástica - eram realizados e contabilizados na Provedoria-Mor da Fazenda Real e Contadoria da Bahia. ${ }^{90}$

As circunscrições jurisdicionais dos ouvidores e capitães-mores de Sergipe, embora tivessem o mesmo centro, a cidade de São Cristóvão, nem sempre foram coincidentes. O primeiro ouvidor-geral, nomeado em 1696, tinha jurisdição desde o Rio São Francisco, ao norte, até Itapoã, ao sul. A carta-régia de 27 de abril de 1729, recua essa divisória para o rio Subauma, ${ }^{91}$ reduzindo o espaço de atuação dos ouvidores, mas que, todavia, continuava sendo mais amplo que o dos capitães-mores, restrito aos termos da cidade de São Cristóvão e das vilas de Santo Amaro das Brotas, Santa Luzia do Rio Real, Lagarto, Itabaiana e Vila Nova do São Francisco. Circunstâncias pontuais podiam alterar esses limites. Em 1736, por exemplo, como decorrência de desordens ocorridas em Jeremoabo, o vice-rei, conde das Galveas, passou a

\footnotetext{
${ }^{87}$ Revista do Instituto Histórico e Geográfico Brasileiro, v. 245, 1959. Relatório do governador João Alberto de Miranda Ribeiro ao vice-rei conde de Resende, em 17.11.1797.

${ }^{88}$ NUNES, 1996, p. 155.

${ }^{89}$ Ordem régia a d. João de Lancastro, Governador-geral do Estado do Brasil, em 16.2.1696. In: PRADO, I. do. A capitania de Sergipe e suas Ouvidorias, op. cit., pp. 179 e 180.

${ }^{90}$ Ver relação completa das despesas da Provedoria da Bahia em CALDAS, J. A. Notícia Geral..., op. cit., p. 25 et passim.

${ }^{91}$ PRADO, 2015, p. 180 e 283.
} 
jurisdição militar dessa vila para a capitania de Sergipe, por sua proximidade, mas deixou-a vinculada a comarca da ouvidoria geral da Bahia. ${ }^{92}$

Os governos de Santa Catarina e do Rio Grande de São Pedro tiveram, cada qual, uma provedoria da fazenda a partir de 1750. A necessidade em administrar um maior volume de gastos do ampliado aparelho militar, possivelmente foi um dos fatores a justificar a existência do referido órgão. Mas, como ocorria com Sergipe em relação à Bahia, o controle das receitas e despesas principais era realizado pela fazenda real do Rio de Janeiro. A ouvidoria geral, instaurada um ano antes, com sede na vila de N. Sra. do Desterro, tinha jurisdição sobre o território dos dois governos, à exceção de São Francisco do Sul. Esta vila foi um caso extremo do desencontro de jurisdições naquele período. Atuavam nela, em 1816, o ouvidor da comarca de Paranaguá, o bispo do Rio de Janeiro, a Junta da Fazenda de São Paulo, e, no militar, o governador de Santa Catarina. ${ }^{93}$ Portanto, as jurisdições do governo, ouvidoria e provedoria tinham como sede central a ilha, mas com circunscrições não-coincidentes.

\section{CONSIDERACÕES FINAIS}

As formas de organização política e administrativa da América portuguesa variaram muito no tempo e no espaço. As soluções institucionais adotadas, amparadas na ordem jurídica (escrita e costumeira), tinham por objetivo responder às necessidades econômicas, políticas e sociais específicas da monarquia portuguesa diante das condições concretas existentes.

A capitania-mor de Sergipe del Rei e o governo da ilha de Santa Catarina foram, antes de tudo, instituições militares preparadas para a guerra e administradas pelo poder régio. A militarização serviu para evitar que reinos estrangeiros concorrentes avançassem sobre o espaço; expulsar, dominar ou mesmo exterminar povos originários; e servir de poder coercitivo legítimo ao ordenamento social e produtivo da colônia, debelando mocambos, prendendo soldados desertores, criminosos e infratores, e dando suporte aos ouvidores, juízes e provedores para execução da justiça e administração dos rendimentos.

\footnotetext{
${ }^{92}$ AHU, Sergipe, cx. 5, d. 27. Carta do vice-rei a d. João V, em 11.6.1736.

${ }^{93}$ BRITO, 1829, p. 107.
} 
Viu-se, no entanto, que esses corpos militares, estruturados em regimentos de infantaria das tropas pagas ( $1^{\mathrm{a}}$ linha), terços de auxiliares ( $2^{\mathrm{a}}$ linha) e companhias de ordenanças ( $3^{\mathrm{a}}$ linha $)$, tiveram pesos distintos nos dois estabelecimentos. As tropas de $1^{\mathrm{a}}$ linha do governo da ilha de Santa Catarina foram muito superiores às de Sergipe, o que exigiu um número maior de oficiais do exército para comandá-los e, à frente deles, um comandante-chefe de mais alta patente, um governador-coronel. A manutenção do elevado contingente militar, assim como dos fortes e fortalezas, significou também alto investimento em soldos, fardas, rações e armamentos, o que talvez justifique a existência de uma provedoria da fazenda para sua administração, órgão inexistente na capitania de Sergipe.

A estrutura militar diferenciada evidencia características peculiares de um e outro. O governo da ilha de Santa Catarina desempenhou a função de base militar para domínio e defesa não só da ilha, bem como desse vasto território entre São Paulo e o rio da Prata, que se valorizara no século XVIII. Constituiu-se também como importante unidade produtiva vinculada aos circuitos atlânticos. A capitania de Sergipe del Rei desempenhou da mesma forma um papel na geopolítica portuguesa na América. Porém, findo o conflito com os holandeses, ela se consolidou como uma unidade fundamentalmente produtiva. Seu corpo militar, de igual modo significativo - mas muito mais estruturado nas companhias de ordenanças - voltou-se antes para o ordenamento social e econômico interno do que para combater ameaças externas.

No que diz respeito ao estatuto e posição hierárquica, constatou-se que os termos "governo" e "capitania", "governadores" e "capitães", embora utilizados de modo flexível, não tinham o mesmo significado. O uso preferencial de um ou outro (ou da combinação de ambos) pelos contemporâneos expressava distinções, que poderiam ser apenas honoríficas, em decorrência do status do titular do cargo, ou indicar diferenças do próprio estabelecimento. Se os capitães-mores de Sergipe almejavam agregar o título de "governador" ao seu posto, os governadores de Santa Catarina tinham por ambição acrescentar o de "capitão-general". Distinções nas formas de tratamento, no soldo que auferiam no exercício do cargo, assim como também na própria estrutura institucional mostraram que as "governadorias" subalternas ao Rio de Janeiro encontravam-se numa posição hierárquica intermediária entre as capitanias-mores da Bahia e as capitanias-gerais. 
Quanto à condição de subalternidade, viu-se que a capitania de Sergipe foi instalada, no final do século XVI, como unidade dependente ao governo-geral do Estado do Brasil, como estavam todas as demais capitanias reais e de donatários. No decorrer do tempo, governadoresgerais/vice-reis tomam ela como uma das partes da capitania da Bahia. Já o governo da ilha de Santa Catarina foi subalterno à capitania-geral do Rio de Janeiro desde sua fundação, em 1738. Nesse século, a projeção política e econômica do Rio de Janeiro, da Bahia, e de Pernambuco no mundo Atlântico refletiu diretamente no controle que esses centros passaram a exercer sobre suas anexas. As reformas políticas com o propósito de fortalecimento do poder régio tiveram como resultado na América portuguesa a concentração do poder em torno não de uma capital, mas das capitanias-gerais. A transferência da capital do vice-reinado, em 1763, desdobramento da mudança de prioridades da monarquia, do Norte para o Centro-Sul, acabou por provocar um mesmo efeito para Sergipe e Santa Catarina: a redução ainda maior da autonomia políticainstitucional.

A análise empírica dessas instituições nos ajuda a desfazer também aquela percepção historiográfica que localizava, nos séculos XVII e XVIII, unidades estatais muito coesas, com suas jurisdições civis, militares e fazendárias perfeitamente justapostas. A noção de que a capitania formava a maior unidade administrativa da colônia, dividindo-se seu território em comarcas, as comarcas em termos e os termos em freguesias ${ }^{94}$, não se aplica plenamente aos dois casos aqui estudados, nos quais a circunscrição jurisdicional dos ouvidores foi, por vezes, mais ampla que a dos capitães-mores e dos governadores.

Cabe registrar, por fim, que o quadro esboçado aqui não esgota as complexas relações de poder entre os diferentes agentes da administração portuguesa. Procurou-se mostrar um aspecto formal do poder - incompleto, diga-se, tendo em vista outros planos institucionais eclesiásticos, jurídicos e militares - que pouco diz sobre as dinâmicas e os equilíbrios ajustados com outros setores da sociedade, mas que tampouco se pode compreender sem ele.

${ }^{94}$ PRADO Jr., C. Formação do Brasil Contemporâneo - colônia. 23 ed. São Paulo: Brasiliense, 1999, p. 306. 


\section{REFERÊNCIAS}

\section{Fontes}

ARQUIVO DO ESTADO DE SÃO PAULO (AESP), Documentos Interessantes para a história e costumes de São Paulo, v. XVIII, p. 8 e 9.

ARQUIVO HISTÓRICO ULTRAMARINO (AHU), Bahia, Coleção Castro e Almeida, caixas. 3,5 ,

. Bahia, Avulsos, caixa 89.

. Sergipe, caixas $1,2,3,5,6,7,8$.

. Códice 112.

Santa Catarina, caixas 3, 4, 5, 6 .

ARQUIVO NACIONAL DA TORRE DO TOMBO (ANTT), Chancelaria de D. Maria I, Lv. 78; Registro Geral de Mercês, D. João V, Lv. 3 e 14; D. José I, Lv. 8.

ARQUIVO NACIONAL DO RIO DE JANEIRO (ANRJ), Fundo 86, Códice 106, v. 2, f. 211; v. 3 (final) e v. 4.

ARQUIVO PÚBLICO DO ESTADO DA BAHIA (APEB), Seção de Arquivo Colonial e Provincial - Gov-Geral/Gov. da capitania-mor de Sergipe (1767-1799), mç. 190.

BIBLIOTECA NACIONAL. Anais da Biblioteca Nacional do Rio de Janeiro, v. XXXIX, pp. 80,99 e 142. indicados.

Documentos Históricos da Biblioteca Nacional do Rio de Janeiro (DHBN), anos

BLUTEAU, R. Vocabulário Portuguez e Latino... Coimbra: Collegio das Artes da Companhia de Jesu, 1712, 8v.

BRITO, P. J. M. de. Memória política sobre a capitania de Santa Catarina. Lisboa, 1829 [1816].

CALDAS, J. A. Notícia Geral de Toda Esta Capitania da Bahia desde o seu descobrimento até o presente ano de 1759. Salvador: Tipografia Beneditina, 1951 [Edição fac-similar].

COLEÇÃO DE LEIS DO IMPÉRIO DO BRASIL, 1809, v. 1. Disponível em: $<$ https://www2.camara.leg.br/legin/fed/carreg_sn/anterioresa1824/cartaregia-40047-14-abril1809-571617-publicacaooriginal-94762-pe.html>. Acesso em: jun. 2020. 
Documentos sobre a Colônia do Sacramento e expedição que a foi socorrer em 1736. Revista do Instituto Histórico e Geográfico do Rio Grande do Sul, 1948, n. 109 a 112.

MENDONÇA, M. C. de. Raízes da Formação Administrativa do Brasil - Tomo II Regimentos XVII a XXXIII. Rio de Janeiro: IHGB; Conselho Federal de Cultura, 1972.

Relatório do governador João Alberto de Miranda Ribeiro ao vice-rei conde de Resende, em 17.11.1797. Revista do Instituto Histórico e Geográfico Brasileiro, v. 245, 1959.

\section{Obras Gerais}

ALENCASTRO, L. F. de. O trato dos viventes: formação do Brasil no Atlântico Sul, século XVI e XVII. São Paulo: Companhia das Letras, 2000.

ALMEIDA, L. F. de. A diplomacia portuguesa e os limites meridionais do Brasil (1493-1700). Coimbra: Universidade de Coimbra, 1957 (v. I).

AMARAL, B. do. Limites do Estado da Bahia (Bahia - Sergipe). Salvador: Imprensa Oficial do Estado, 1916.

ANTÔNIO, E. M. M. A Independência do solo que habitamos: poder, autonomia e cultura política na construção do Império Brasileiro. Sergipe (1750-1831). São Paulo: Editora UNESP, 2012.

Correspondências e cultura política na América Portuguesa: cartas e uma rebelião colonial. Revista Brasileira de História da Mídia (RBHM) - v. 5, n. 1, jan/2016 - jun/2016.

ARAÚJO, H. A. F. F. A construção da governabilidade no Estado do Brasil: perfil social, dinâmicas políticas e redes governativas do governo-geral (1642-1682). Tese (Doutorado em História), Instituto de História, Programa de Pós-graduação em História Social, Universidade Federal do Rio de Janeiro, Rio de Janeiro, 2018.

AVELLAR, H. de A. Administração Pombalina. 2 ed. Brasília: Fundação Centro de Formação do Servido Público; Universidade de Brasília, 1983 (vol. 5 - História Administrativa do Brasil).

BLOCH, M. Para uma história comparada das sociedades europeias. Id. História $e$ historiadores. Lisboa: Teorema, 1948.

BOMFIM, A. G. do. As capitanias de Itaparica e Tamarandiva e do Paraguaçu: administração, direito de propriedade e poder na América Portuguesa (c.1530 - c.1630). Salvador: PPG História da Faculdade de Filosofia e Ciências Humanas da UFBA, 2016.

BOXER, C. Salvador de Sá e a luta pelo Brasil e Angola, 1602-1686. Trad. Olivério de Oliveira Pinto. São Paulo: Ed. Nacional: EDUSP, 1973 (Brasiliana, v. 353). 
CABRAL, O. R. Santa Catarina (História - evolução). São Paulo: Companhia Editora Nacional, 1937 (Col. Brasiliana, v. 80).

CARNAXIDE, V. de. O Brasil na administração pombalina: economia e política externa. Rio de Janeiro: Companhia Editora Nacional, 1940.

CHAVES, J. I. As capitanias de Pernambuco: política e administração na América Portuguesa (sécs. XVII-XVIII). Belo Horizonte: Fino Traço, 2021.

COELHO, M. J. d'A. Memória histórica da Província de Santa Catarina. 2. ed. Desterro: Tip. J. J. Lopes, 1877. [1. ed. 1853].

CORREA, C. H. P. História de Florianópolis - ilustrada. Florianópolis: Insular, 2004.

COSENTINO, F. C.: Hierarquia política e poder no Estado do Brasil: o governo-geral e as capitanias, 1654-1681. Topoi. Rio de Janeiro, v. 16, n. 31, p. 515-543, jul/dez., 2015.

. Governadores gerais do Estado do Brasil (séculos XVI-XVII): ofício, regimentos, governação e trajetórias. São Paulo: Annablume/FAPEMIG, 2009.

. Construindo o Estado do Brasil: instituições, poderes locais e poderes centrais. In: FRAGOSO, J.; GOUVÊA, M. de F. O Brasil Colonial, 1443-1580. v. I. Rio de Janeiro: Civilização Brasileira, 2014.

CUNHA, M. S. da.; MONTEIRO, N. G. Governadores e capitães-mores do império atlântico português nos séculos XVII e XVIII. In: MONTEIRO, N. G.; CARDIM, P.; CUNHA, M. S. da. (Org). Optima Pars: elites ibero-americanas do Antigo Regime. Lisboa: Imprensa de Ciências Sociais, 2005.

CURVELO, A. A. S. de C. Governar Pernambuco e as "capitanias anexas": o perfil de recrutamento, a comunicação política e as jurisdições dos governadores da capitania de Pernambuco (c.1654 - c.1756). Tese (Doutorado em História), Programa Interuniversitário de Doutoramento em História. Universidade de Lisboa, ISCTE - Instituto Universitário de Lisboa, Universidade Católica Portuguesa e Universidade de Évora, 2019.

ENCICLOPÉDIA Luso-Brasileira de Cultura. Lisboa: Verbo, s/d, vol. IX.

FREIRE, F. História de Sergipe (1575-1855). 3ª ed. São Cristóvão: Ed UFS, 2013.

HANDELMANN, H. História do Brasil. 4. ed. São Paulo: Itatiaia, 1982, p. 36. [1. ed. alemã: 1860].

HARO, M. A. P. de (Org). Ilha de Santa Catarina: relatos de viajantes estrangeiros nos séculos XVIII e XIX. 3 ed. Florianópolis: EdUFSC; Lunardelli, 1990.

HESPANHA, A. M. Poder e Instituições na Europa do Antigo Regime (coletânea de textos). Lisboa: Fundação Calouste Gulbenkian, 1984. 
As estruturas políticas em Portugal na Época Moderna. In: TENGARRINHA, J. (Org). História de Portugal. 2 ed. Bauru, SP: EDUSC, UNESP; Lisboa: Instituto Camões, 2001.

; SANTOS, M. C. "Os poderes num império oceânico". In: HESPANHA, A.M. (Coord). História de Portugal - v. 4, O Antigo Regime (1620-1807). Lisboa: Estampa, 1998.

LIMA Jr., F. de C. História dos limites entre Sergipe e Bahia. São Cristóvão: Ed. da UFS; Aracaju: IHGSE, 2015 [1919].

MENDONÇA, M. C. de. Raízes da Formação Administrativa do Brasil - Tomo II Regimentos XVII a XXXIII. Rio de Janeiro: IHGB; Conselho Federal de Cultura, 1972.

MONTEIRO, N. G. Elites e poder: entre o Antigo Regime e o liberalismo. Lisboa: ICS, 2003.

. Governadores e capitães-mores do império atlântico português no século XVIII. In: BICALHO, M. F. B.; FERLINI, V. (Org). Modos de governar: ideias e práticas políticas no império português - séculos XVI a XIX. São Paulo: Alameda, 2005.

MORAES, A. C. R. Bases da formação territorial do Brasil: o território colonial brasileiro no "longo" século XVI. São Paulo: Hucitec, 2000.

; COSTA, W. M. da. A valorização do espaço. São Paulo: Hucitec, 1984.

MOTT, L. R. Sergipe del Rei: população, economia e sociedade. Aracaju: FUNDESC, 1986.

NUNES, M. T. Sergipe colonial I. 2 ed. São Cristóvão: Ed. UFS; Aracaju: Fundação Oviedo Teixeira, 2006.

Sergipe Colonial II. Rio de Janeiro: Tempo brasileiro, 1996.

PAIVA, J. G. de O. Notícia geral da Província de Santa Catarina. In: DICIONÁRIO topográfico, histórico e estatístico da Província de Santa Catarina. Florianópolis: IHGSC, 2003 (Col. Catariniana, 5). [1. ed. 1868]

PIAZZA, W. F. A epopéia açórico-madeirense (1747-1756). Florianópolis: EdUFSC; Lunardelli, 1992.

Santa Catarina: sua história. Florianópolis: Ed. UFSC; Lunardelli, 1983.

PINHEIRO, J. F. F. (Visconde de São Leopoldo). Resumo histórico da Província de Santa Catarina. Anais da Província de São Pedro. Porto Alegre: Mercado Aberto, 1982 (Série Documenta, 11). [1. ed. c. 1832]

PRADO Jr. C. Formação do Brasil Contemporâneo: colônia. 23 ed. São Paulo: Brasiliense, 1999. 
PRADO, I. do. A Capitania de Sergipe e suas Ouvidorias (Memória sobre questões de limites). 2 ed. São Cristóvão: Editora da UFS; Aracaju: IHGSE, 2015.

RIBEIRO, M. da S. Divisão Governativa do Estado do Brasil e a Repartição do Sul. XII Encontro Regional de História - ANPUH, Rio de Janeiro, 2006.

ROLIM, A. Jurisdição militar, inquisitorial e territorial no sul de Pernambuco: contribuição a uma arquitetura dos poderes nas capitanias de Porto Calvo, Alagoas e Rio de São Francisco (1655-1712). Revista Ultramares, n. 2, v. 2, jan/jul. 2012, pp. 130-159.

RUSSELL-WOOD, A. J. R. "A projeção da Bahia no Império Português". In: Anais do $4^{o}$ Congresso de História da Bahia. [Salvador 450 anos], 27 de setembro a $1^{\circ}$ de outubro de 1999. Salvador: Instituto Geográfico e Histórico da Bahia; Fundação Gregório de Matos, 2001.

SALDANHA, A. V. de. As capitanias do Brasil: antecedentes, desenvolvimento e extinção de um fenómeno atlântico. Lisboa: Comissão Nacional para as Comemorações dos

Descobrimentos Portugueses, 2001.

SCHWARTZ, S. Segredos internos: engenhos e escravos na sociedade colonial. São Paulo: Companhia das Letras, 1988.

SILVA, A. da. O governo da ilha de Santa Catarina e sua terra firme: território, administração e sociedade (1738-1807). Rio de Janeiro: Arquivo Nacional, 2013.

SIQUEIRA, L. Homens de mando e de guerra: capitães-mores em Sergipe del Rey (16481743). Tese (Doutorado em História), Universidade Federal da Bahia, Salvador, 2016.

TILLY, C. "War Making and State Making as Organized Crime". In: EVANS, P. B.; RUESCHEMEYER, D.; SKOCPOL, T. (Eds). Bringing the State Back In. Cambridge: Cambridge Universtiy Press, 1985, p. 169-191.

VARNHAGEN, F. A. de. História Geral do Brasil. 5 ed. São Paulo: Edições Melhoramentos, 1956.

VIANA, F. V. Estudo sobre a origem histórica dos limites entre Sergipe e Bahia. Salvador: Typ. e Enc. Do Diário da Bahia, 1891.

VIANNA, H. História do Brasil colonial. São Paulo, 1945.

WEHLING, A. Administração Portuguesa no Brasil de Pombal a D. João (1777-1808). Brasília-DF: Fundação Centro de Formação do Servido Público, 1986 (vol. 6 - História Administrativa do Brasil). 